\title{
Az elhízás mozgásszervi vonatkozásai: egy régi téma új megközelítésben
}

\author{
Tamási László dr. ${ }^{1}$ - Miksi Ágnes dr. ${ }^{1}$ - Kardos Zsófia dr. ${ }^{1}$ \\ Flórián Ágnes dr. ${ }^{1}$. Szekanecz Zoltán dr. ${ }^{2}$
}

\author{
${ }^{1}$ Borsod-Abaúj-Zemplén Megyei Központi Kórház és Egyetemi Oktatókórház, Szent Ferenc Tagkórház, \\ Reumatológiai Osztály, Miskolc \\ ${ }^{2}$ Debreceni Egyetem, Általános Orvostudományi Kar, Belgyógyászati Intézet, Reumatológiai Tanszék, Debrecen
}

\begin{abstract}
A szerzők az elhízás mozgásszervi vonatkozásait új megközelítésben, elsősorban annak metabolikus hatásait kiemelve ismertetik. Az elhízással és különösen a metabolikus szindrómával járó biokémiai változások megváltoztatják a csont, az ízületi struktúrák és az izomzat múködését. Ezek alapján szemléletváltozás szükséges bizonyos kórképekben az eddig kialakult nézetekben. A gyulladásos reumatológiai betegségek lefolyásának súlyosságában és az alkalmazott kezelések megválasztásában is figyelembe kell venni az elhízással járó anyagcsere-változásokat. A társuló komorbiditások miatt a személyre szabott kezelés fontossága kiemelt jelentőségú.
\end{abstract}

Orv Hetil. 2019; 160(44): 1727-1734.

Kulcsszavak: elhízás, metabolikus szindróma, mozgásszervi betegségek, osteoarthrosis, arthritis, adipokinek, leptin

\section{Musculoskeletal relevance of obesity: a new approach to an old topic}

Authors discuss the musculoskeletal aspects of obesity by applying a novel approach. Biochemical changes associated with obesity and especially metabolic syndrome, may have a great impact on the function of bones, joints and muscles. Therefore we need a new view and new strategies in rheumatic diseases. Obesity-associated metabolic changes should be considered during the progress of as well as the selection of treatment in inflammatory rheumatic diseases. Individualised treatment is necessary due to associated comorbidities as well.

Keywords: obesity, metabolic syndrome, musculoskeletal diseases, osteoarthrosis, arthritis, adipokines, leptin

Tamási L, Miksi Á, Kardos Zs, Flórián Á, Szekanecz Z. [Musculoskeletal relevance of obesity: a new approach to an old topic]. Orv Hetil. 2019; 160(44): 1727-1734.

(Beérkezett: 2019. június 9.; elfogadva: 2019. július 2.)

\begin{abstract}
Rövidítések
ACPA $=($ anti-citrullinated protein antibodies $)$ anticitrullináltprotein-ellenanyagok; ASAS40 $=($ Assessment in Spondyloarthritis International Society $40 \%$ ) a Nemzetközi Gerinctársaság szerinti kritérium; BASDAI $=$ (bath ankylosing spondylitis disease activity index) bath spondylitis ankylopoetica betegség aktivitási indexe; BASFI $=$ (bath ankylosing spondylitis functional index) bath spondylitis ankylopoetica funkciós indexe; BAS-G = (bath ankylosing spondylitis patient global score) bath SpA-beteg-index; bDMARD = (biological disease-modifying antirheumatic drug) biológiai betegséget módosító reumaellenes gyógyszer; BMD = (bone mineral density) csontsúrüség; $\mathrm{BMI}=$ (body mass index) testtömegindex; $\mathrm{CI}=$ (confidence interval) konfidenciaintervallum; $\mathrm{CRP}=(\mathrm{C}$-reactive protein) C-reaktív protein; $\mathrm{CT}=($ computed tomography $)$
\end{abstract}

számítógépes tomográfia; $\mathrm{CV}=$ cardiovascularis; csDMARD = (conventional synthetic disease-modifying antirheumatic drug) hagyományos szintetikus betegséget módosító, reuma elleni gyógyszer; DANBIO = (biological therapies in Denmark $)$ dán biológiai terápiák; DEXA = (dual energy X-ray absorptiometry) kettős energiájú röntgensugár-elnyelődés mérése; EIRA = (epidemiological investigation of rheumatoid arthritis) a rheumatoid arthritis epidemiológiai vizsgálata; GIP = (gastric inhibitory polypeptide) gasztrikus inhibitorikus polipeptid; HDLC = (high-density lipoprotein cholesterol $)$ magas sűrúségű lipoproteinkoleszterin; HLA = humán leukocytaantigén; HPA = (hypothalamic-pituitary-adrenal) hypothalamus-hypophysismellékvese; HR-pQCT = (peripheral quantitative computed tomography) perifériás kvantitatív számítógépes tomográfia; ICEBIO = (Icelandic biological therapies) izlandi biológiai 
terápiák; IDF $=($ International Diabetes Federation $)$ Nemzetközi Diabetes Szövetség; IGF1 = (insulin-like growth faktor 1) inzulinszerü növekedési faktor-1; IL6 = interleukin-6; JAK = Janus-kináz; LDA = (low disease activity $)$ alacsony betegségaktivitás; LDLC $=($ low-density lipoprotein cholesterol $)$ alacsony sűrüségű lipoproteinkoleszterin; MS = (metabolic syndrome) metabolikus szindróma; MTX = (methotrexate) metotrexát; NAFLD $=$ (non-alcoholic fatty liver disease $)$ nem alkoholos zsírmájbetegség; $\mathrm{NK}=$ (natural killer) természetes ölősejt; NSAID $=$ (nonsteroidal anti-inflammatory drug $)$ nemszteroid gyulladáscsökkentő szer; $\mathrm{OA}=$ osteoarthrosis; ODM = oszteodenzitometria; $\mathrm{OPG}=$ oszteoprotegerin $; \mathrm{OR}=$ (odds ratio) esélyhányados; PsA $=$ (psoriatic arthritis) arthritis psoriatica; $\mathrm{RA}=$ rheumatoid arthritis; $\mathrm{RANK}=$ (receptor activator nuclear factor kappa B) receptoraktivátor nukleáris faktor kappa-B; RANKL = RANK-ligand; $\mathrm{RR}=$ (relative risk) relatív rizikó; $\mathrm{SO}=$ (sarcopenic obesity) sarcopeniás obesitas; $\mathrm{SpA}=$ spondylarthritis; T2DM = (type 2 diabetes mellitus) 2-es típusú diabetes mellitus; $\mathrm{TNF} \alpha=$ (tumor necrosis factor alpha) tumornekrózisfaktor-alfa; $\mathrm{T}_{\mathrm{REG}}=$ (regulatory $\mathrm{T}$-cells) regulatorikus T-sejtek; VAT $=($ visceral adipose tissue $)$ visceralis zsírtömeg; $\mathrm{WHO}=($ World Health Organization $)$ Egészségügyi Világszervezet

Az elhízás gyakoriságának növekedése világméretű probléma, mely jelentős egészségügyi kockázatot jelent. A WHO adatai szerint 2016-ban több mint 1,9 milliárd, 18 éves és idősebb ember volt a Földön túlsúlyos, közülük 650 millió elhízott. Fontos adat az is, hogy az 5-9 év közötti elhízott fiatalok száma 340 millió, ezen belül az 5 év alatti túlsúlyos vagy elhízott gyermekek száma 41 millió. 1975 és 2016 között az előfordulási gyakoriság közel a háromszorosára növekedett [1]. Magyarországon a Központi Statisztikai Hivatal 2016-2017-ről szóló jelentése szerint a lakosság több mint felének, a testtömegindex (BMI) alapján, súlytöbblete van. Ezen belül $35,8 \%$ túlsúlyos,18,3\% enyhén és 3,8\% súlyosan elhízott. A 15 éven felüliek 40\%-a tekinthető normál testsúlyúnak, a soványabbak aránya az 5\%-ot sem éri el [2].

Az elhízás leggyakoribb egészségügyi következményei a cardiovascularis (CV-) megbetegedések (2012-ben vezetô halálok volt); diabetes mellitus; mozgásszervi betegségek (elsősorban a degeneratív ízületi betegségek); bizonyos daganatok (például endometrium, emló, petefészek, prosztata, máj, húgyhólyag, vese, vastagbél) [2, 3]. A gyermekkori elhízás a felnőttkori elhízás, a korai halálozás és a mozgáskorlátozottság jelzője lehet, de további rizikók is társulnak hozzá, mint a légzési nehezítettség, törési kockázat, hipertónia, CV-kórképek, inzulinrezisztencia és pszichológiai elváltozások [2].

Az elhízás és a mozgásszervi betegségek között szignifikáns összefüggés van. Egy felmérés szerint az Egyesült Államokban az elhízott betegek több mint 31\%-a fordult orvoshoz mozgásszervi panaszokkal, szemben a nem túlsúlyos egyének 16\%-ával [3]. Az elhízás és a társuló mozgásszervi megbetegedések következménye a mozgáskorlátozottság és az életminôség romlása [3]. A leggyakoribb, elhízáshoz társuló mozgásszervi kórképeket

\section{1. táblázat | Elhízáshoz társuló mozgásszervi kórképek}

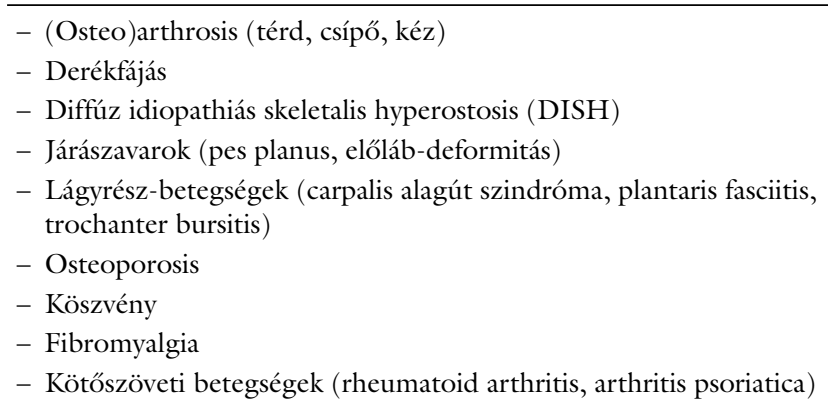

az 1. táblázat mutatja. Külön kiemeljük, hogy hazánkban, többek között, Pados Gyula [4] és Halmy László [5] professzorok végeztek kiemelkedő kutatómunkát az elhízás területén.

\section{A metabolikus szindróma}

Az utóbbi években az anyagcsere-kutatások középpontjába került az elhízás. A metabolikus szindróma (MS) az elhízás különleges formája, melyben a testsúly növekedéséhez más kóros anyagcsere-elváltozások is társulnak $[6,7]$. A MS alkatilag is elkülöníthető a túlsúlyosságtól, mert ebben az esetben, az esetek nagyobb részében, a hasi zsírszövet felszaporodása dominál („alma” típus) (2. táblázat). A MS definíciója a WHO 1998-as meghatározása után több módosításon esett át. A 2. táblázat a Nemzetközi Diabetes Szövetség (International Diabetes Federation; IDF) 2005-ös ajánlását tartalmazza [6, 7]. A kritériumok közül legalább három tényező együttes jelenléte szükséges a MS diagnózisának megállapításá-

2. táblázat A metabolikus szindróma kritériumai az IDF ajánlása szerint* [6]

\footnotetext{
- Hasi elhízás a haskörfogat alapján

- férfiaknál $\geq 102 \mathrm{~cm}$

- nóknél $\geq 88 \mathrm{~cm}$

- Szérumtriglicerid-szint $\geq 1,7 \mathrm{mmol} / 1$

- Csökkent HDLC-szint

- férfiaknál $\leq 1,03 \mathrm{mmol} / 1$

- nóknél $\leq 1,29 \mathrm{mmol} / 1$

- Vérnyomás $\geq 130 / 85$ Hgmm

- vagy kezelt hypertonia

- Éhomi vércukor $\geq 5,6 \mathrm{mmol} / 1$

- vagy T2DM
}

*Megjegyzés: A Magyar Diabetes Társaság az inzulinrezisztenciára jel lemző kóros HOMA-IR-értéket is felvette a kritériumok közé $(>4,4)$.

HDLC = magas sűrűségű lipoproteinkoleszterin; HOMA-IR = az éh gyomri vércukor- és inzulinszintértékekből kerül kiszámolásra; IDF = Nemzetközi Diabetes Szövetség; T2DM = 2-es típusú cukorbetegség 
hoz. A felmérések alapján a világ lakosságának 10-25\%-a szenved MS-ban [6]. Szigethy és mtsai [8] hazai felmérése során háziorvosi adatbázisból véletlenszerúen kiválasztott 2000, 20-69 év közötti lakos kérdőíves felmérése során férfiakban 26\%-ban, nőkben 24\%-ban találtak MS-t.

A MS jelentőségét az adja, hogy összefüggést mutat számos CV-kockázati tényezővel (alacsony HDLC-, magas LDLC- és trigliceridszint, hypertonia), az inzulinrezisztenciával, a 2-es típusú diabetesszel (T2DM). Újabban az is ismertté vált, hogy a MS talaján a daganatos betegségek, egyes pszichiátriai kórképek, az alvási apnoe szindróma és a nem alkoholos zsírmáj (NAFLD) is gyakoribb [6]. Hazánkban elsőként Suba és mtsai [9] közöltek a MS-val kapcsolatos adatokat.

Bár a MS patofiziológiai háttere nem teljesen ismert, az említett alapvető anyagcsere-folyamatok (inzulinrezisztencia, centrális elhízás) mellett más tényezők (például hypothalamus-hypophysis-mellékvese; HPA-) tengely, immunrendszeri aktiváció, stressz, gyulladásos citokinek, adipokinek) is szerepet kapnak. Ennek kapcsán kimutatták, hogy a hasi adiposus szövet nem csupán egy passzív teher a szervezetben, hanem aktív endokrin szervként múködik. Számos bioaktív mediátort szekretál, és ennek következtében egy alacsony szintű krónikus gyulladást („low-grade inflammation”) tart fenn. Szövettani vizsgálatokkal igazolták, hogy a zsírszövet adipocytái hypoxia, oxidatív stressz hatására megszaporodnak, hipertrofizálnak. A zsírszövetben a kapillárisokon keresztül zajló sejtes infiltráció jelenik meg. Ennek elemei a neutrofilek, makrofágok, NK-sejtek, $\mathrm{T}_{\mathrm{H}} 2$-típusú lymphocyták, hízósejtek és fibroblastok. Az Ml-típusú makrofágok inflammatoricus, M2-fenotípusra változnak, és fontos szerepük van a krónikus gyulladás fenntartásában (metainflammatio). A lymphocyták vonatkozásában, a $\mathrm{T}_{\mathrm{H}} 1 / \mathrm{T}_{\mathrm{H}} 2$ egyensúly megváltozik, a $\mathrm{T}_{\mathrm{H}} \mathrm{l}$ és a CD8+ T-sejtek száma nő, míg a CD4+ és regulatorikus T-sejtek $\left(\mathrm{T}_{\mathrm{REG}}\right)$ száma csökken. A gyulladásos citokinek, így a tumornekrózisfaktor-alfa (TNF $\alpha)$, az interleukin-6 (IL6) mennyisége nő. Adipokinek (adiponektin, leptin, rezisztin, viszfatin, kemerin) halmozódnak fel a zsírszövetben. Az utóbbi arra utal, hogy a visceralis zsírszövet nem csupán passzív energiarezervoár, hanem az energiahomeosztázist aktívan befolyásolja [10].

Ami a MS és a mozgásszervek összefüggéseit illeti, az elhízás és annak különleges formája, a visceralis elhízás a fent ismertetett metabolikus változások következtében jelentôs hatással van a csont, az ízületi struktúrák és a vázizomzat fiziológiás múködésére. Emellett a gyulladásos reumatológiai kórképek lefolyását, valamint az alkalmazott kezelés hatékonyságát is módosítja. Míg a proporcionális elhízásnak elsősorban a mechanikai hatása érvényesül a mozgásszervekben, addig a metabolikus elhízás a metainflammatio révén fejti ki hatását. A közleményekben nem mindig különül el e két elhízásforma, talán ezzel magyarázható az eredmények különbözősége [11].

\section{Elhízás és osteoarthrosis}

Az arthrosis (osteoarthrosis, OA) multifaktoriális betegség, melynek kialakulásában számos rizikótényező játszik szerepet (2. táblázat). Az életkor előrehaladtával az OA elófordulása növekszik, 70 év felett a lakosság 40\%-ában kimutatható [12].

Populációs vizsgálatokban kimutatták, hogy az elhízás szignifikáns rizikófaktora a tibiofemoralis, a csípő-, a patellofemoralis és kéz-OA-nak (3. táblázat) [13]. Mostanáig elsősorban az ízületek fizikai túlterhelését tekintették az elhízás legfontosabb mozgásszervi következményének. Emellett azonban az elhízás szerepet játszik a lágyrész-struktúrák (ín, fascia, porc) mechanikai sérülésében is. A mechanikai teória a legáltalánosabban elfogadott az OA kialakulása szempontjából, azonban meglepően kevés direkt tudományos bizonyíték van a biomechanika megváltozására elhízott egyénekben. Feltételezik, hogy a túlsúlyosság más rizikótényezőkkel együtt, azok hatását erôsítve fejti ki hatását. Ebben olyan lokális faktorok is részt vesznek, mint az ízület használata, a járásforma, az ízületi struktúra és az izomzat állapota, gyengesége $[11,13]$. Érdekes módon a kéz-csukló OA gyakoribb előfordulását is kimutatták elhízásban $[13,14]$. A Rotterdam-vizsgálat szignifikáns összefüggést mutatott ki az elhízás és a kéz-OA között, ám közös metabolikus hátteret nem talált [14]. A szerzők azonban már felvetették a leptin lehetséges szerepét az elhízáshoz társuló OA-ban. Ezek a megfigyelések a biomechanikai okokon túl az elhízáshoz társuló metabolikus elváltozások felé irányították a figyelmet [14]. Néhány, nem randomizált klinikai vizsgálat kimutatta, hogy a testsúlycsökkentő diéta és a fizikai aktivitás hatásosan csökkenti a térdfájdalmat és a járászavart [15]. Az ADAPT-vizsgálatban 316, túlsúlyos vagy elhízott térdarthrosisos beteget 18 hónapon keresztül vizsgáltak. Diéta és fizikális aktivitás mellett, bár a testsúly csak mérsékelten csökkent, a fájdalom és a fizikális funkció szignifikánsan javult. A tartós testsúlycsökkentő diéta mellett a leptinszint szignifikánsan csökkent. A kiindulási alacsonyabb leptinszint mellett nagyobb testsúlycsökkenést tapasztaltak. Magas leptinszintet mértek azon betegekben, akiknek a funkcionális állapota roszszabb volt [16].

3. táblázat |Az arthrosis rizikótényezői

$$
\begin{aligned}
& \text { - Genetika } \\
& \text { - Életkor } \\
& \text { - Nem } \\
& \text { - Etnikum } \\
& \text { - Csontmetabolizmus } \\
& \text { - Hormonok } \\
& \text { - Táplálkozás } \\
& \text { - Elhízás } \\
& \text { - Fizikai terhelés }
\end{aligned}
$$




\section{Csontanyagcsere és elhízás}

Az elhízás és a csontmetabolizmus közötti kapcsolat komplex és nem tisztázott teljesen: részben mechanikus, részben metabolikus tényezőkön nyugszik. Az utóbbi évek kutatásai hívták fel a figyelmet a metabolikus hatások fontosságára. Az adipocyták és az osteoblastok közös őssejtből származnak. A lokális szöveti miliő megváltozása befolyásolhatja, hogy mely sejttípus irányába tolódik el a sejtdifferenciálódás. A csökkent csontképződés fokozott adipogenezissel jár [17, 18].

A leptin a nem mechanikus kapcsolatot biztosítja az elhízás és a csont között, függetlenül a kortól, a nemtól, a BMI-től. A leptin mellett a D-vitamin, a proinflammatoricus citokinek, a csontvelői mikrokörnyezet lokális faktorai is fontos szerepet kapnak. A leptin citokinszerü hormon, amely az adipocytákban termelődik, de a chondrocytákban, a synoviocytákban és az immunsejtekben is expresszálódik. A leptin a csontmetabolizmusban direkt és indirekt módon vesz részt, centrális és perifériás mechanizmus révén. A leptin anorexigen és proinflammatoricus kettős hatású; részt vesz a veleszületett immunitásban; gátolja a NK-sejteket; serkenti a monocyták proliferációját és aktivációját; az adaptív immunválasz során pedig aktiválja a T- és B-sejteket, és serkenti a citokintermelést. Az anyagcserehatások tekintetében a leptinnek fó szerepe van a központi energiahomeosztázis szabályozásában. Befolyásolja az étvágyat, a táplálékfelvételt, a csonttömeget, az alapanyagcserét, a reproduktív funkciókat és az inzulinszekréciót. Szintje a keringésben korrelál a fehér zsírszövet mennyiségével. A centrális leptinrezisztenciának fontos szerepe van a diabetes patomechanizmusában. A porcban proinflammatoricus, prokatabolikus, ízületi degenerációt okoz. Kulcsszerepe van az OA és az arthritisek patofiziológiájában: OA-ban és rheumatoid arthritisben (RA) katabolikus hatású, az osteoblastfunkciót, a subchondralis chondrogen progenitor sejteket gátolja, míg a proinflammatoricus citokinek termelődését, az osteoclastaktivációt és a csontbontást fokozza $[17,19,20]$.

Ami a csontanyagcserére gyakorolt hatások hátterét illeti, elhízásban a korábban már ismertetett „low-grade inflammation" során olyan metabolitok képződnek, melyek a csontmetabolizmusra negatív hatással vannak (például $\mathrm{TNF} \alpha$, IL6, leptin, adiponektin). A keringő leptin direkt módon hat a csontsejtekre, és fokozza a csontképzést, ha azonban a hatása a hypothalamuson keresztül érvényesül, gátlóhatást fejt ki a szimpatikus idegrendszer fokozott aktivációja révén. Az adiponektinszint inverz módon függ össze a BMD-vel, befolyásolja a csontanyagcserében kifejezetten fontos receptoraktivátor nukleáris faktor kappa-B (RANK) / RANK-ligand (RANKL) / oszteoprotegerin (OPG) jelátvitelt. Az adiponektin, a leptinhez hasonlóan, a központi idegrendszeren át is kifejti hatását. A pancreasban és a bélben termelődő hormonok (inzulin, amilin, preptin, grelin, gastric inhibitory polypeptide [GIP], glükagonszerü peptid) szintén hatással vannak a csontmetabolizmusra. A lokális zsírszövet metabolikus aktivitása a test különböző területein más és más, így a csontrendszerre való hatása is változó $[10,17]$.

Ami a csont biokémiai markereket illeti, elhízásban a reszorpciós markerek mennyisége meghaladja a formációs markerekéit. Elhízott férfiakban csökkent a növekedési hormon $(\mathrm{GH})$, az inzulinszerü növekedési faktor-1 (IGFl) és a tesztoszteron szintje. A visceralis zsírtömeg és a csontvelőzsír a csont mikroszerkezetének és mechanikai tulajdonságának károsodásával függ össze, míg az izomtömeg kedvező hatású a csontszerkezetre. A csökkent tesztoszteron- és GH-szint károsan befolyásolja a mikroarchitektúrát, míg az ösztradiol protektív hatású $[17,21]$.

Külön kell szólnunk a D-vitamin szerepéről. Elhízásban $\mathrm{D}$-vitamin-hiány mutatható ki, mivel a D-vitamin nagyobb része kumulálódik a zsírszövetben, és nem jut vissza a keringésbe. A D-vitamin-szint szignifikánsan, fordítottan arányos a BMI-vel [17, 22].

Az elhízás és a csonttömeg összefüggéseinek vizsgálatát nagyban elősegítette, amikor a csontsűrüség vizsgálatára kifejlesztett oszteodenzitométerekkel (ODM) vizsgálni kezdték a test lágyrész-összetételét, és ennek révén a zsírtömegról és az izomzat mennyiségéről számszerű adatok jelentek meg [17]. Salamat és mtsai [23] a BMI alapján meghatározott elhízott betegekben csökkent osteoporosisrizikót és magasabb BMD-t mutattak ki. Feltételezték, hogy a zsírszövet és a lágyrész-tömeg részt vesz a csonttömeg megtartásában a csontok mechanikai terhelése révén. Általánosan elfogadott ténynek tekintették, hogy a jelentős lágyrész-tömeg pozitív hatással van az axialis és perifériás csontokra [23]. Az újabb vizsgálatok azonban, melyek a lágyrészen belül az izomzat és a zsír összetételét, annak részesedését a BMI-ben ('body composition') külön vizsgálták, ellenkező eredményeket mutattak. Az utóbbi munkacsoportok azt találták, hogy a centrális elhízás összefüggést mutat az alacsony BMDvel és a magasabb törési rizikóval $[17,24]$.

Chen és mtsai [25] a közelmúltban különböző elhízástípusokban és metabolikusan egészséges elhízottakban elsőként vizsgálták a BMD-t. Azt találták, hogy a BMI alapján meghatározott elhízás szignifikánsan összefüggött az emelkedett BMD-vel, míg a testzsírszázalék alapján definiált elhízás a csökkent BMD-vel [25]. Mint láttuk, korábbi vizsgálatok is magasabb BMD-értéket mértek magasabb testtömeg esetén, mely alapján igazoltnak látszott az az álláspont, hogy a kövér emberek védettek lennének az osteoporosissal szemben [23]. Amennyiben azonban a magas testtömegen belül a testzsír mennyiségével összefüggésben vizsgálták a csontdenzitást, megdőlt a korábbi álláspont, és bebizonyosodott, hogy az elhízás nem véd a csontritkulással szemben $[17,24]$.

Ami az elhízás és a törési kockázat összefüggéseit illeti, az újabb vizsgálatok az mutatták, hogy az elhízás nem véd a csonttörésekkel szemben sem $[17,26]$. A Sadeghi 
és mtsai [26] által csaknem 300 ezer elhízott egyénen végzett metaanalízis szerint az abdominalis elhízás szignifikánsan magasabb csípőtáji törési relatív rizikóval (RR) járt (RR: 1,24; 95\% CI: 1,05-1,46; p = 0,01) a nem elhízott egészségesekkel szemben. Más vizsgálatokban a csípő-, medence- és csuklótörések alacsonyabb, míg a boka- és egyéb alsó végtagi törések magasabb rizikóját figyelték meg $[17,27]$. Mindezen különbségekben szerepet játszhat az esések típusa, a csípő körüli zsírtömeg erőbehatást csökkentő szerepe, valamint nemi és földrajzi különbségek is $[17,26,27]$. Liu és mtsai [27] 710 betegben elsőként vizsgálták magas felbontású, perifériás kvantitatív CT-vel (HR-pQCT) a trabecularis és a corticalis csont mikroarchitektúráját a visceralis zsírtömeg (VAT) függvényében. A magasabb VAT nagyobb BMD-vel és jobb mikroszerkezettel társult a perifériás csontokon. A nem teherviselő radiuson a corticalis csonton csökkent corticalis csontdenzitást, szignifikánsan fokozott porozitást észleltek. A trabecularis denzitás és trabeculaszám fokozott volt. A szerzők a VAT hatását a csontrendszerre inkább a mechanikai terhelés következményének, mint metabolikus hatásnak tekintik [27].

\section{Elhízás, sarcopenia és a csont}

Egészséges fiatal és felnőtt egyénekben a csontozat és az izomzat harmonikusan növekszik. Ezt a harmóniát a nehézségi erő biztosítja, melyet a mechanoreceptorok közvetítenek az izomzat és a csont felé, de különböző növekedési faktorok módosítanak. Adatok vannak arra vonatkozólag, hogy az alacsony izomtömeg és izomminőség erősen negatív prognosztikai hatással van az elhízott egyénekre, csonttörékenységet, mozgáskorlátozottságot, fokozott morbiditást és mortalitást okozva. Mindezt a sarcopeniás obesitas (SO) fogalma fejezi ki [28]. Meghatározása szerint SO áll fenn, ha 2SD-nél alacsonyabb a DEXA-val mért végtagizomzat tömeg/testmagasság $\mathrm{m}^{2}$ (izomtömegindex) a fiatal, referenciaizomtömeghez képest [28]. A sarcopenia és az elhízás sokkal szorosabban kapcsolódik a rokkantsághoz, mint bármely más testösszetétel-változás önmagában. A MS előfordulása SO-ban (19\%) magasabb, mint a normál$(10,7 \%)$ és sarcopeniás nem elhízott csoportban $(3,7 \%)$ $[28,29]$.

Elhízott, idős egyénekben csökkent az izomtömeg, károsodott az izomfunkció, és osteoporosis is felléphet. Scott és mtsai [29] vizsgálatában 50 éves és idősebb SObetegekben az alacsonyabb alsó végtagi izomtömeg magasabb proximalis tibia-BMD-vel társult, és negatívan függött össze a posturalis kilengéssel. Ez arra utal, hogy a fokozott törési kockázat feltehetően a rossz izomtömeg és -funkció következménye. Az izomzat zsíros infiltrációja negatív hatással van a lokális csontminőségre, feltehetően a helyi gyulladás miatt. SO-ban szignifikánsan alacsonyabb volt az ágyéki csigolyák, a teljes csípő, a distalis radius és tibia teljes, valamint a proximalis radius és tibia corticalis BMD-je. A sarcopenia szignifikánsan gyakrabban okozott eleséseket [29].

\section{Elhízás és gyulladásos ízületi betegségek}

Az elhízás/MS és a gyulladásos reumatológiai kórképek kapcsolata többrétű. Az elhízás fokozhatja az arthritisek kialakulásának rizikóját. Emellett az elhízás és MS a társbetegségek miatt befolyásolhatja az alapbetegség súlyosságát, lefolyását és a gyógyszeres terápiára adott választ is [30-32].

\section{Rheumatoid arthritis}

Az utóbbi években mind az elhízás prevalenciája, mind a RA incidenciája emelkedett. Az elhízás és a RA közti kapcsolatot, azaz hogy az elhízás a RA rizikófaktora lehet, több vizsgálat, közöttük néhány nagyobb metaanalízis is megerősítette [30-33]. Qin és mtsai [33] metaanalízisükben megállapították, hogy pozitív korreláció áll fenn a BMI és a RA rizikója között. Az elhízottakban 24\%-kal fokozódott a RA kockázata a normál testsúlyúakhoz képest. Az alcsoportvizsgálatokban a relatív rizikó magasabb volt a nókben az átlagpopulációhoz képest [33].

Már a magasabb születési súly is RA-ra hajlamosíthat. Ami a rizikó mértékét illeti, Qin és mtsai [33] metaanalízisében az elhízás 1,25-szörös rizikófokozódást jelentett a RA szempontjából. A hajlam korrelált a BMI-vel. Míg $25 \mathrm{~kg} / \mathrm{m}^{2}$ BMI esetén a rizikó 1,2-szeres, addig ez 40 $\mathrm{kg} / \mathrm{m}^{2}$ mellett már 1,5-szörös volt [33]. Feng és mtsai [34] összesen 13 tanulmány metaanalízisét végezték el 13500 RA-betegen és 400 ezer kontrollon. Az elhízás 1,22-szeres rizikót jelentett. A BMI minden $5 \mathrm{~kg} / \mathrm{m}^{2}$-es növekedése 1,12-szeresére növelte az esélyt. Itt is igazolódott, hogy a szeronegatív RA-val való összefüggés szorosabb: itt a rizikó 1,47-szeresnek bizonyult [34]. E tekintetben a betegségtartam is fontos lehet. Hosszan fennálló RA esetén a MS kockázata 87\%, míg korai RA esetén csupán 16-31\% volt [35].

Az elhízás és a RA összefüggéseinek hátterében patogenetikai faktorok állhatnak. Az autoantitestek vonatkozásában Pedersen és mtsai [36] azt találták, hogy az elhízás a leginkább a szeronegatív RA rizikóját fokozza. Lu és mtsai [37] viszont mind az ACPA-pozitív, mind a szeronegatív nőkben magasabbnak találták a RA kockázatát elhízás esetén, és erősebb összefüggés volt az ACPA-pozitivitással. Az ACPA-status szerepének pontos tisztázása az elhízás és a RA iránti fogékonyság összefüggésének szempontjából még további vizsgálatokat igényel. Az autoimmunitás mellett fontos lehet a genetika szerepe is. Az elhízás valószínúleg a HLA-DR3-hordozással összefüggésben hajlamosít RA-ra [36]. Az elhízás emellett számos egyéb mechanizmus révén erôsíti a proinflammatoricus folyamatokat, és ezáltal fokozhatja a RA 
kialakulását. Elsődlegesen a zsírban deponálódó adipokinek, valamint az inzulinrezisztencia szerepe fontos [20, 31].

\section{Arthritis psoriatica}

$\mathrm{Az}$ arthritis psoriatica (PsA) összefüggése az elhízással még kifejezettebb, mint RA esetében. Li és mtsai [38] nagy beteganyagot felölelő amerikai prospektív vizsgálatukban, 18 év feletti nőkben progresszív rizikófokozódást találtak az incidens PsA tekintetében. Kevesebb, mint $25 \mathrm{~kg} / \mathrm{m}^{2}$ BMI esetén a RR 1,83, $25 \mathrm{~kg} / \mathrm{m}^{2}$ BMInél a RR 3,12, $30 \mathrm{~kg} / \mathrm{m}^{2}$ BMI-nél a RR 5,11, míg 35 $\mathrm{kg} / \mathrm{m}^{2}$ BMI felett a RR 6,46 volt. Ez 10\%-os rizikóemelkedést jelent 4,5 kg-onként [38].

Eder és mtsai [39] korai PsA-betegeket arthritis nélküli psoriasisos betegekkel összehasonlítva magasabbnak találták az elhízás előfordulását PsA-ban (OR: 1,77; p = 0,002). A magasabb BMI az idősebb életkori kezdettel és a HLA-B27-negativitással (OR: 2,39; p<0,001) függött össze. Normál testsúlyúakban a korai kezdet és a HLA-B27-pozitivitás gyakoribb volt, mint elhízottakban $(\mathrm{p}=0,002)$. Ez alapján a szerzők felvetik a különböző patogenetikai faktorok szerepét a gyulladásos folyamat létrejöttében [39].

\section{Axialis spondylarthritis}

Relatíve kevés közlemény jelent meg az axialis spondylarthritis (SpA) metabolikus eltéréseivel kapcsolatban. Maas és mtsai [40] vizsgálatában a BMI mérése alapján az axialis SpA-betegek 37\%-a volt túlsúlyos, és 22\%-uk volt elhízott, ami az átlagpopulációhoz képest szignifikánsan magasabb volt. Az elhízott betegek betegségaktivitása, fizikális funkciója, valamint életminősége szignifikánsan rosszabb volt a túlsúlyos és normál testsúlyú betegekhez képest [40]. Lee és mtsai [41] ázsiai városi populációban (PRESPOND-adatbázis, 2011-2015) axialis SpA-ban a túlsúlyos betegek arányát 32\%-nak, az elhízottakét 22\%-nak találták. Az elhízottakban a fájdalom mértéke és a bath SpA-beteg-index (bath ankylosing spondylitis patient global score; BAS-G) magasabb volt. Ezzel szemben a BASDAI-, BASFI-indexek, valamint az SF-36 fizikai és mentális komponensei nem különböztek az elhízott és normál súlyú betegekben [41].

\section{Az elhízás hatása a gyógyszeres kezelés hatékonyságára}

\section{Rheumatoid arthritis}

Sandberg és mtsai [42] a korai RA-betegeket magában foglaló EIRA-kohorszban magasabb BMI mellett roszszabb terápiás választ észleltek metotrexátra (MTX). Ugyancsak kisebb volt az alacsony betegségaktivitás (low disease activity; LDA) elérésének esélye [42]. Lupoli és mtsai [43] metaanalízisükben összesen 17 tanulmány és 6693 beteg (5131 RA és 1562 PsA) adatait dolgozták fel. Az LDA-t konvencionális szintetikus (csDMARD) és biológiai betegségmódosító szerekkel (bDMARD) elhízottakban szignifikánsan ritkábban tudták elérni, mint normál testsúlyúakban, és a betegek lassabban is érték el a javulást. Fiatal férfiakban jobb volt az eredmény [43]. Érdekes módon több vizsgálatban is közölték, hogy az elhízás csökkent ízületi károsodással és radiológiai progresszióval jár együtt RA-ban [31]. Ennek pontos mechanizmusa nem ismert. Lehetséges, hogy bizonyos adipokinek, mint az adiponektin, mely elhízásban fokozottan termelődik, az ízületi destrukció szempontjából protektív hatású [31].

Bizonyos vizsgálatok szerint a zsírszövet tömege öszszefügg a TNF $\alpha$-rezisztenciával. A TNF $\alpha$-gátló kezelés kevéssé hatásos magas BMI esetén, és a TNF $\alpha$-gátló utáni második szer hatékonyságát is csökkenti. Ezzel szemben a testsúlycsökkenés javítja a terápiás választ [31, 32, 44]. Vidal és mtsai [44] metaanalízisükben 58 közlemény adatait elemezték. Nagyobb BMI-érték esetén a kezelés hatására elért DAS28- és HAQ-index magasabb volt, mint normáltestsúly esetén [44].

Az egyéb, nem TNF-gátló bDMARD-ok közül a különböző vizsgálatok alapján a testsúly/BMI nem befolyásolja az IL6-receptor-gátló tokilizumab, a T-sejt-kostimuláció-gátló abatacept és a B-sejt-gátló rituximab hatékonyságát $[30,31]$.

A terápia kapcsán nemcsak a testtömegre és a BMI-re, hanem a testösszetételre gyakorolt hatás is fontos lehet. Tournadre és mtsai [45] egyéves tokilizumabkezelés alatt figyelték meg a BMI emelkedése mellett az izomtömeg emelkedését a zsírtömeg változása nélkül. Ugyanakkor csökkent a törzs/periféria aránya, és növekedett a subcutan zsírszövet [45]. Moisan és mtsai [46] tanulmányában tofacitinib hatására a fehér zsírszövet metabolikusan kevéssé aktív barna zsírszövetté alakult, amit a JAK-gátlás jellegzetes hatásaként értékelnek.

A fentiek alapján a gyakorlat szempontjából lényeges figyelnünk a testsúly- és testösszetétel-változásokra. Egyrészt a jelentősebb fogyás (rheumatoid cachexia) jelent rosszabb prognózist. Másrészt a beteg kezelésével a testsúly növekszik, és ilyenkor a TNF-gátló adagját esetleg igazítanunk kell. A beteg „valódi” testtömegét és BMIjét mindenképpen remisszióban vagy LDA-ban javasolt meghatározni [31].

\section{Arthritis psoriatica}

Mint láttuk, a magas BMI, különösen fiatalkorban, független rizikófaktora lehet a psoriasisnak és a PsA-nak. A terápia során elhízottakban kisebb a lehetőség az LDA elérésére [47, 48].

Ami a bDMARD-kezelés hatékonyságát illeti, Højgaard és mtsai [47] a dán (DANBIO) és izlandi (ICEBIO) biológiai terápiás regiszter adatai alapján több mint 1000 PsA-betegben vizsgálták a TNF $\alpha$-gátlók hatá- 
sát. A betegek egyharmada volt elhízott. A bDMARDkezelés eredményessége csekélyebb volt az elhízottakban, főleg a férfiakban. Ebben a csoportban több volt a hatástalanság miatti kezelésmegszakítás is. A szerzők rámutatnak, hogy a TNF-gátlók hatékonyságában szerepet játszhat a TNF $\alpha$-gátlók elhízásban megváltozott farmakokinetikája, a szöveti eloszlás, valamint a testsúlytól független dozírozás [47]. Iannone és mtsai [48] olasz PsA-betegeken nem mutatták ki az elhízás negatív hatását a kezelés eredményességére. A különbségek hátterében földrajzi eltérések is állhatnak. Számos adat utal arra, hogy Skandináviában, genetikai és életmódi okokból, az arthritis súlyosabb és nehezebben kezelhető, mint a mediterrán országokban $[30,36,48]$.

\section{Axialis spondylarthritis}

SpA-ban az első adatokat a TNF $\alpha$-kezelés eredményessége és a testtömeg összefüggéséról Ottaviani és mtsai [49] közölték 155 beteg kezelése kapcsán. A BASDAI szerinti betegségaktivitás, a CRP és az NSAID-igény magasabb volt az elhízottak csoportjában. Ez mutatta a testtömegtől függó csökkent terápiás hatékonyságot [49]. Micheroli és mtsai [50] 624 axialis SpA-beteget kezeltek TNF-gátlóval. A betegek közül 204 túlsúlyos és 88 elhízott volt. Az elhízott betegek idősebbek, magasabb BASDAI-aktivitásúak voltak, és funkcionális károsodásuk is kifejezettebb volt. Egyéves anti-TNF-kezelés után az elhízottakban szignifikánsan alacsonyabb ASAS40 szerinti választ mértek [50].

\section{Következtetés}

Az elhízás önmagában és a MS részeként számos ponton összefügg a reumatológiai kórképekkel és kezelésükkel. A metabolikus, immunológiai, gyulladásos mechanizmusok révén az elhízás szerepet játszik az arthrosis, az osteoporosis és a gyulladásos reumatológiai kórképek kialakulásában. A testtömeg és a testösszetétel jelentős hatással lehet a társbetegségekre, az alkalmazott kezelés hatékonyságára és valószínúleg a mortalitásra is.

Anyagi támogatás: A munka az Európai Unió Szociális Alap TÁMOP-4.2.4.A/2-11/1-2012-0001 „Nemzeti Kiválóság Program” (Sz. Z.), valamint az Európai Unió GINOP-2.3.2-15-2016-00015 és GINOP-2.3.2-152016-00050 (Sz. Z.) támogatásával készült.

Szerzöi munkamegosztás: T. L.: A téma felvetése, a cikk megírása. M. Á.: Adatgyújtés, közremúködés a cikk írásában. K. Zs., F. Á.: Irodalomkutatás. Sz. Z.: Részvétel a cikk írásában és a végső forma kialakításában. A cikk végső változatát valamennyi szerző elolvasta és jóváhagyta.

Érdekeltségek: A szerzőknek a közlemény megírásával kapcsolatban nincsenek érdekeltségeik.

\section{Irodalom}

[1] WHO. Obesity and overweight. World Health Organization, Geneva, 2018. Available from: https://www.who.int/newsroom/fact-sheets/detail/obesity-and-overweight [accessed: June 9, 2019].

[2] Health status and health behaviour 2016-2017. [Egészségi állapot és egészségmagatartás, 2016-2017]. Központi Statisztikai Hivatal, Statisztikai tükör, 2018. július 23. [Hungarian]

[3] Anandacoomarasamy A, Caterson I, Sambrook P, et al. The impact of obesity on the musculoskeletal system. Int J Obes (Lond). 2008; 32: 211-222.

[4] Pados Gy. Current treatment of obesity. [Az elhízás korszerú kezelése.] Orv Hetil. 2010; 151: 501-504. [Hungarian]

[5] Halmy L, Fehér T, Steczek K, et al. High serum bile acid level in obesity: its decrease during and after total fasting. Acta Med Hung. 1986; 43: 55-58.

[6] Alberti KG, Zimmet P, Shaw J, et al. The metabolic syndrome - a new worldwide definition. Lancet 2005; 366: 1059-1062.

[7] International Diabetes Federation. The IDF consensus worldwide definition of the metabolic syndrome. [A Nemzetközi Diabetes Társaság (IDF) ajánlása a metabolikus szindróma világszerte érvényes definíciójára.] Diabetol Hung. 2005; 13: 107-112. [Hungarian.]

[8] Szigethy E, Széles G, Horváth A, et al. Epidemiology of the metabolic syndrome in Hungary. Public Health 2012; 126: 143149.

[9] Suba I, Halmos T, Kautzky L. The value of certain parameters in the diagnosis and detection of metabolic $\mathrm{X}$ syndrome. [Az egyes vizsgálati paraméterek értéke a metabolikus X-szindróma diagnózisában és felkutatásában.] Orv Hetil. 1997; 138: 2407-2411. [Hungarian]

[10] Nishimura S, Manabe I, Nagai R. Adipose tissue inflammation in obesity and metabolic syndrome. Discov Med. 2009; 8: 55-60.

[11] Collins KH, Herzog W, MacDonald GZ, et al. Obesity, metabolic syndrome, and musculoskeletal disease: common inflammatory pathways suggest a central role for loss of muscle integrity. Front Physiol. 2018; 9: 112.

[12] Szekanecz Z. Osteoarthritis. In: Szekanecz Z, Nagy Gy. (eds.) Rheumatology. [Osteoarthritis. In: Szekanecz Z, Nagy Gy. (szerk.) Reumatológia.] Medicina Könyvkiadó, Budapest, 2019; pp. 451-470. [Hungarian]

[13] Cicuttini FM, Baker JR, Spector TD. The association of obesity with osteoarthritis of the hand and knee in women: a twin study. J Rheumatol. 1996; 23: 1221-1226.

[14] Dahaghin S, Bierma-Zeinstra SM, Koes BW, et al. Do metabolic factors add to the effect of overweight on hand osteoarthritis? The Rotterdam Study. Ann Rheum Dis. 2007; 66: 916-920.

[15] Rejeski WJ, Focht BC, Messier SP, et al. Obese, older adults with knee osteoarthritis: weight loss, exercise, and quality of life. Health Psychol. 2002; 21: 419-426.

[16] Miller GD, Nicklas BJ, Davis CC, et al. Is serum leptin related to physical function and is it modifiable through weight loss and exercise in older adults with knee osteoarthritis? Int J Obes Relat Metab Disord. 2004; 28: 1383-1390.

[17] Miksi Á, Fazekas K, Flórián Á, et al. Relationship between metabolic syndrome and osteoporosis. [A metabolikus szindróma és az osteoporosis összefüggései.] Immunol Szle. 2018; 10: 4-9. [Hungarian]

[18] Rosen CJ, Klibanski A. Bone, fat, and body composition: evolving concepts in the pathogenesis of osteoporosis. Am J Med. 2009; 122: 409-414.

[19] Francisco V, Pino J, Campos-Cabaleiro V, et al. Obesity, fat mass and immune system: role for leptin. Front Physiol. 2018; 9: 640.

[20] Abella V, Scotece M, Conde J, et al. Leptin in the interplay of inflammation, metabolism and immune system disorders. Nat Rev Rheumatol. 2017; 13: 100-109. 
[21] Bredella MA, Lin E, Gerweck AV, et al. Determinants of bone microarchitecture and mechanical properties in obese men. J Clin Endocrinol Metab. 2012; 97: 4115-4122.

[22] Carrelli A, Bucovsky M, Horst R, et al. Vitamin D storage in adipose tissue of obese and normal weight women. J Bone Miner Res. 2017; 32: 237-242.

[23] Salamat MR, Salamat AH, Janghorbani M. Association between obesity and bone mineral density by gender and menopausal status. Endocrinol Metab (Seoul). 2016; 31: 547-558.

[24] Janicka A, Wren TA, Sanchez MM, et al. Fat mass is not beneficial to bone in adolescents and young adults. J Clin Endocrinol Metab. 2007; 92: 143-147.

[25] Chen YY, Fang WH, Wang CC, et al. Body fat has stronger associations with bone mass density than body mass index in metabolically healthy obesity. PLoS ONE 2018; 13: e0206812.

[26] Sadeghi O, Saneei P, Nasiri M, et al. Abdominal obesity and risk of hip fracture: a systematic review and meta-analysis of prospective studies. Adv Nutr. 2017; 8: 728-738.

[27] Liu CT, Broe KE, Zhou Y, et al. Visceral adipose tissue is associated with bone microarchitecture in the Framingham Osteoporosis Study. J Bone Miner Res. 2017; 32: 143-150.

[28] Stenholm S, Harris TB, Rantanen T, et al. Sarcopenic obesity: definition, cause and consequences. Curr Opin Clin Nutr Metab Care 2008; 11: 693-700.

[29] Scott D, Johansson J, McMillan LB, et al. Associations of sarcopenia and its components with bone structure and incident falls in Swedish older adults. Calcif Tissue Int. 2019; 105: 26-36.

[30] Finckh A, Turesson C. The impact of obesity on the development and progression of rheumatoid arthritis. Ann Rheum Dis. 2014; 73: 1911-1913.

[31] Kerekes G, Nurmohamed MT, Gonzalez-Gay MA, et al. Rheumatoid arthritis and metabolic syndrome. Nat Rev Rheumatol. 2014; 10: 691-696

[32] Singh S, Facciorusso A, Singh AG, et al. Obesity and response to anti-tumor necrosis factor-alpha agents in patients with select immune-mediated inflammatory diseases: a systematic review and meta-analysis. PLoS ONE 2018; 13: e 0195123.

[33] Qin B, Yang M, Fu H, et al. Body mass index and the risk of rheumatoid arthritis: a systematic review and dose-response meta-analysis. Arthritis Res Ther. 2015; 17: 86.

[34] Feng J, Chen Q, Yu F, et al. Body mass index and risk of rheumatoid arthritis: a meta-analysis of observational studies. Medicine (Baltimore) 2016; 95: e2859.

[35] da Cunha VR, Brenol CV, Brenol JC, et al. Metabolic syndrome prevalence is increased in rheumatoid arthritis patients and is associated with disease activity. Scand J Rheumatol. 2012; 41: 186-191.

[36] Pedersen M, Jacobsen S, Klarlund M, et al. Environmental risk factors differ between rheumatoid arthritis with and without auto-antibodies against cyclic citrullinated peptides. Arthritis Res Ther. 2006; 8: R133.

[37] Lu B, Hiraki LT, Sparks JA, et al. Being overweight or obese and risk of developing rheumatoid arthritis among women: a prospective cohort study. Ann Rheum Dis. 2014; 73: 1914-1922.
[38] Li W, Han J, Qureshi AA. Obesity and risk of incident psoriatic arthritis in US women. Ann Rheum Dis. 2012; 71: 1267-1272.

[39] Eder L, Abji F, Rosen CF, et al. The association between obesity and clinical features of psoriatic arthritis: a case-control study. J Rheumatol. 2017; 44: 437-443.

[40] Maas F, Arends S, van der Veer E, et al. Obesity is common in axial spondyloarthritis and is associated with poor clinical outcome. J Rheumatol. 2016; 43: 383-387.

[41] Lee YX, Kwan YH, Png WY, et al. Association of obesity with patient-reported outcomes in patients with axial spondyloarthritis: a cross-sectional study in an urban Asian population. Clin Rheumatol. 2017; 36: 2365-2370.

[42] Sandberg ME, Bengtsson C, Källberg H, et al. Overweight decreases the chance of achieving good response and low disease activity in early rheumatoid arthritis. Ann Rheum Dis. 2014; 73 : 2029-2033.

[43] Lupoli R, Pizzicato P, Scalera A, et al. Impact of body weight on the achievement of minimal disease activity in patients with rheumatic diseases: a systematic review and meta-analysis. Arthritis Res Ther. 2016; 18: 297.

[44] Vidal C, Barnetche T, Morel J, et al. Association of body mass index categories with disease activity and radiographic joint damage in rheumatoid arthritis: a systematic review and metaanalysis. J Rheumatol. 2015; 42: 2261-2269.

[45] Tournadre A, Pereira B, Dutheil F, et al. Changes in body composition and metabolic profile during interleukin 6 inhibition in rheumatoid arthritis. J Cachexia Sarcopenia Muscle 2017; 8: 639-646.

[46] Moisan A, Lee YK, Zhang JD, et al. White-to-brown metabolic conversion of human adipocytes by JAK inhibition. Nat Cell Biol. 2015; 17: 57-67.

[47] Højgaard P, Glintborg B, Kristensen LE, et al. The influence of obesity on response to tumour necrosis factor-alpha inhibitors in psoriatic arthritis: results from the DANBIO and ICEBIO registries. Rheumatology (Oxford) 2016; 55: 2191-2199.

[48] Iannone F, Fanizzi R, Scioscia C, et al. Body mass does not affect the remission of psoriatic arthritis patients on anti-TNF- $\alpha$ therapy. Scand J Rheumatol. 2013; 42: 41-44.

[49] Ottaviani S, Allanore $Y$, Tubach F, et al. Body mass index influences the response to infliximab in ankylosing spondylitis. Arthritis Res Ther. 2012; 14: R115.

[50] Micheroli R, Hebeisen M, Wildi LM, et al. Impact of obesity on the response to tumor necrosis factor inhibitors in axial spondyloarthritis. Arthritis Res Ther. 2017; 19: 164.

(Szekanecz Zoltán dr., Debrecen, Nagyerdei krt. 98., 4032 e-mail: szekanecz.zoltan@med.unideb.hu)

A cikk a Creative Commons Attribution 4.0 International License (https://creativecommons.org/licenses/by/4.0/) feltételei szerint publikált Open Access közlemény, melynek szellemében a cikk bármilyen médiumban szabadon felhasználható, megosztható és újraközölhetö, feltéve, hogy az eredeti szerző és a közlés helye, illetve a CC License linkje és az esetlegesen végrehajtott módositások feltüntetésre kerülnek. (SID_1) 